\section{Efficacy of Paclobutrazol and Uniconazole on Four Bedding Plant Species}

\author{
James E. Barrett and Terril A. Nell \\ Environmental Horticulture Department, University of Florida, \\ Gainesville, FL 32611
}

Additional index words. Impatiens wallerana, Salvia splendens, Tagetes erecta, Petunia
hybrida

Abstract. Impatiens L. wallerana Hook., Salvia splendens Sello ex Nees, Tagetes erecta L., and Petunia hybrida Vilm. plants in $610-\mathrm{cm}^{3}$ pots were sprayed with either uniconazole or paclobutrazol at concentrations from 10 to $160 \mathrm{mg}^{-1 i t e \mathrm{r}^{-1}}$. For all species, both chemicals reduced plant size compared with untreated control plants, and the effect increased with higher concentrations. Uniconazole produced smaller plants than did paclobutrazol at similar concentrations. For impatiens, salvia, and marigold, there was an interaction between chemical and concentration; the degree of difference between the effects of the chemicals was greater at higher concentrations. For these three species, uniconazole elicited a quadratic response and reached saturation within the concentrations used; however, these concentrations were still in the linear portion of the dose response curve for paclobutrazol. Chemical names used: (2RS,3RS)-1-(4-chlorophenyl)-2-(1,1-dimethylethyl)-(1H-1,2,4-triazol-1-yl)pentan-3-ol (paclobutrazol); (E)-(+)(S)-1-(4-chlorophenyl)-4,4-dimethyl-2-(1,2,4-triazol-1-yl)-pent-1-ene-3-ol (uniconazole).

Paclobutrazol and uniconazole effectively reduce stem elongation on various herbaceous crops (Davis et al., 1988). Generally, uniconazole has been more active than paclobutrazol in trials with lilies (Lilium longiflorum Thunb.) (Wilfret, 1987), chrysanthemums [Dendranthema grandiflorium (Ramat.) Kitamura] (Barrett and Nell, 1989, 1990), foliage plants (Wang and Blessington, 1990), and other herbaceous species (Barrett and Nell, 1989; Davis et al., 1987). Therefore, this study was designed to compare the efficacy of paclobutrazol and uniconazole over a range of concentrations on four bedding plant species.

'Super Elfin Red Velvet' impatiens, 'Red Hot Sally' salvia, 'Inca Yellow' marigold, and 'Summer Madness' petunia were obtained as seedlings (plugs) from commercial propagators and planted into $610-\mathrm{cm}^{3}$ pots using Metro Mix 500 (W.R. Grace, Fogelsville, Pa.). Plants were given $150 \mathrm{ppm}$ of $\mathrm{N}$ from a $20 \mathrm{~N}-4.4 \mathrm{P}-16.6 \mathrm{~K}$ fertilizer at each watering. Temperatures ranged from a low of $18 \mathrm{C}$ at night to a daytime high of $27 \mathrm{C}$ in a fiberglass greenhouse with fan-and-pad cooling.

Twenty days after planting, each species was treated with a whole-plant spray of paclobutrazol or uniconazole at 10, 20, 40, 80, or $160 \mathrm{mg} \cdot$ liter $^{-1}$ using a volume of 200

Received for publication 18 Mar. 1991. Accepted for publication 20 Sept. 1991. Florida Agr. Expt. Sta. J. Ser., no. R-01440. The authors express appreciation for the technical assistance of Carolyn Bartuska and the donation of plant material by Natural Beauty of Florida. The cost of publishing this paper was defrayed in part by the payment of page charges. Under postal regulations, this paper therefore must be hereby marked advertisement solely to indicate this fact. $\mathrm{ml} \cdot \mathrm{m}^{-2}$. An untreated control was included for each species but was not included in data analysis. Plant size was determined after 14 days for petunia, 21 days for salvia, and 35 days for impatiens and marigold. Plant size was the average of plant height measured from the pot rim to the top of the plant and plant diameter. Plant diameter was measured in two directions and averaged. Each species was a separate experiment in a randomized complete-block design. There were four replications and three plants per experimental unit. Data were analyzed by analysis of variance and regression analysis.

For the four species, plants were smaller the higher the concentration of the chemicals, and the efficacy of uniconazole was greater than that of paclobutrazol at each concentration (Figs. 1 and 2). For petunia, there was no interaction between chemical

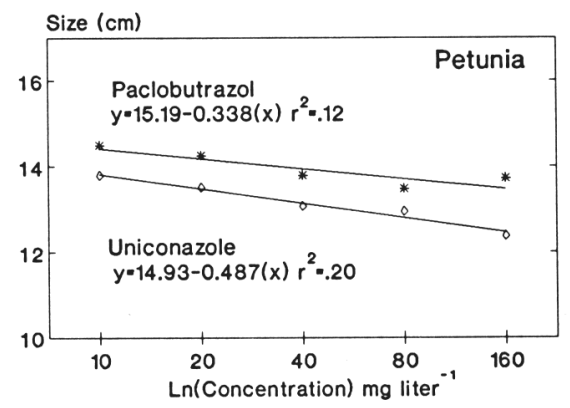

Fig. 1. Plant size (average of height and width) of petunias treated with uniconazole or paclobutrazol. Lines generated from data for individual plants, and points are means for each treatment. Chemical and concentration significant at $P=0.001$ and 0.01 , respectively. Interaction was not significant. Nontreated plant size was $15 \mathrm{~cm}$ and concentration. The only significant regression equation was for the relationship between size and natural log of concentration (Fig. 1). However, there was an interaction between chemical and concentration for impatiens, salvia, and marigold, which indicates that the relative difference in the efficacy of paclobutrazol and uniconazole increased as concentration increased (Fig. 2). Regression analysis gave the best fit for size and paclobutrazol concentration with a linear model, but for uniconazole the best fit was with a quadratic model. A comparison of the slope estimates for the linear and quadratic models was calculated at the concentrations applied, indicating at which concentrations the slope estimates for uniconazole are different from the slope estimates for paclobutrazol. At all applied concentrations, except $160 \mathrm{mg} \cdot \mathrm{liter}^{-1}$ for impatiens and marigold and $80 \mathrm{mg} \cdot \mathrm{liter}^{-1}$ for the salvia, the slopes are different (Table 1).

These results indicate that uniconazole reached a saturation level at the higher concentrations and there was little increase in effect with incremental increases in concentration; whereas these concentrations were

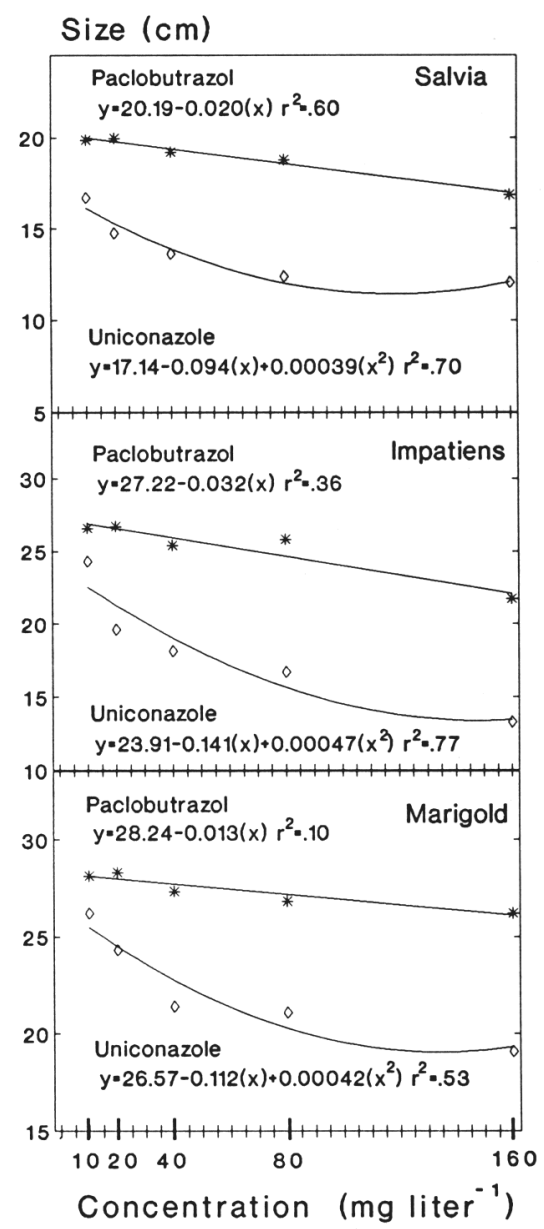

Fig. 2. Plant size (average of height and width) of salvia, impatiens, and marigolds treated with uniconazole or paclobutrazol. Lines generated from data for individual plants, and points are means for each treatment. Chemical $\times$ concentration interactions significant at $P=0.001$, 0.0001 , and 0.02 , respectively. Nontreated plant sizes were 19,28 , and $27 \mathrm{~cm}$, respectively. 
Table 1. Comparisons of simple and quadratic regression slopes at the various rates of chemicals used.

\begin{tabular}{llccccr}
\hline \hline $\begin{array}{l}\text { Bedding } \\
\text { plant }\end{array}$ & & \multicolumn{5}{c}{ Concn (mg·liter-1) } \\
\cline { 3 - 6 } species & Chemical & 10 & 20 & 40 & 80 & 160 \\
\hline Salvia & Paclobutrazol & -0.0203 & -0.0203 & -0.0203 & -0.0203 & -0.0203 \\
& Uniconazole & $-0.0868^{*}$ & $-0.0788^{*}$ & $-0.0630^{*}$ & -0.0312 & $0.0324^{*}$ \\
Impatiens & Paclobutrazol & -0.0320 & -0.0320 & -0.0320 & -0.0320 & -0.0320 \\
& Uniconazole & $-0.1317^{*}$ & $-0.1223^{*}$ & $-0.1034^{*}$ & $-0.0655^{*}$ & 0.1010 \\
Marigold & Paclobutrazol & -0.0133 & -0.0133 & -0.0133 & -0.0133 & -0.0133 \\
& Uniconazole & $-0.1113^{*}$ & $-0.0951^{*}$ & $-0.0785^{*}$ & $-0.0453^{*}$ & 0.0211 \\
\hline
\end{tabular}

*Slope estimate different from paclobutrazol slope estimate at $P=0.01$ as determined by the least significant difference procedure.

still in the linear portion of the response curve for paclobutrazol. In contrast, previous work on chrysanthemums with concentrations from 5 to $160 \mathrm{mg} \cdot \mathrm{liter}^{-1}$ indicated that the saturation level, based on stem elongation, occurred at a lower concentration for paclobutrazol than for uniconazole (Barrett and Nell, 1990).

For salvia, impatiens, and marigold, $\approx 160$ $\mathrm{mg}$ of paclobutrazol/liter was required to produce the same size plant as $10 \mathrm{mg}$ uniconazole/liter; a ratio of 1:16. For petunia, $10 \mathrm{mg}$ of uniconazole and $40 \mathrm{mg}$ of paclobutrazol/liter produced similar-sized plants, a ratio of 1:4. These ratios for salvia, impatiens, and petunia are similar to those found in our previous work, where we also reported a ratio between 1:2 and 1:4 for snapdragon (Antirrhinum majus L.) (Barrett and Nell, 1989). For chrysanthemums, when stem elongation was measured on vegetative plants the ratio was 1:4 (Barrett and Nell, 1990), but the ratio was $\approx 1: 10$ for drench and spray applications on flowering plants (Barrett and Nell, 1989). The data on flowering Easter lily reported by Wilfret (1987) indicated a ratio of 1:33 and 1:66 for drench and spray applications, respectively.

The reason for the differences in the efficacy of paclobutrazol and uniconazole is not clear. The only difference in their mo- lecular structures is a double bond in the center of the uniconazole molecule that is a single bond in paclobutrazol. This location is probably not an active site for growth regulator activity, but likely affects the three-dimensional shape of the molecule and its efficiency for fitting the enzyme receptor site (Davis et al., 1988). Additionally, both molecules exist in different stereoisomers, which have various levels of growth regulator activity (Davis et al., 1988). The manufacturer of paclobutrazol (ICI Agrochemicals, Fernhurst, Haslemere, U.K.) does not separate its two forms, one of which is highly active while the other has only slight growth regulator activity. Therefore, in $100 \mathrm{mg}$ paclobutrazol in the commercial formulation (Bonzi) there are only $\approx 50 \mathrm{mg}$ of active molecules. The manufacturer of uniconazole (Sumitomo Chemical, Osaka, Japan) partially separates the active forms, so in 100 $\mathrm{mg}$ uniconazole in the commercial formulation (Sumagic) there is probably 75 to 90 $\mathrm{mg}$ of active molecules (the actual concentration is proprietary).

The small difference between uniconazole and paclobutrazol molecules and the preparation of the commercial formulations probably contribute to the greater efficacy of uniconazole. These results, along with pre- vious reports, indicate that the relative efficacy of the two chemicals varies widely among species and depends on the concentrations being compared. There can also be differences in vegetative vs. flowering forms of test plants as demonstrated on chrysanthemums (Barrett and Nell, 1989, 1990).

\section{Literature Cited}

Barrett, J.E. and T.A. Nell. 1989. Comparison of paclobutrazol and uniccnazole on floriculture crops. Acta Hort. 251:275-280.

Barrett, J.E. and T.A. Nell. 1990. Factors affecting efficacy of paclobutrazol and uniconazole on petunia and chrysanthemum. Acta Hort. 272:229-234.

Davis, T.D., G.L. Steffans, and N. Sankhla. 1988. Triazole plant growth regulators, p. 63-105. In: J. Janick (ed.). Horticultural reviews. vol. 10. Timber Press, Portland, Ore.

Davis, T.D., H.S. Gehlot, CF. Williams, and N. Sankhla. 1987. Comparative shoot growth-retarding activities of paclobutrazol and XE-1019. Proc. Plant Growth Regulat. Soc. Amer. 14:121124.

Wang, Y.T. and T.M. Blessington. 1990. Growth of four tropical foliage species treated with paclobutrazol or uniconazole. HortScience 25:202204.

Wilfret, G.J. 1987. Height retardation of Easter lilies grown in containers. Proc. Fla. State Hort. Soc. 100:379-382. 